\title{
Social Norms and Social Roles
}

\section{Citation}

Cass R. Sunstein, Social Norms and Social Roles, 96 Colum. L. Rev. 903 (1996).

\section{Published Version}

10.2307/1123430; http://www.jstor.org/stable/1123430

\section{Permanent link}

http://nrs.harvard.edu/urn-3:HUL.InstRepos:12921744

\section{Terms of Use}

This article was downloaded from Harvard University's DASH repository, and is made available under the terms and conditions applicable to Other Posted Material, as set forth at http:// nrs.harvard.edu/urn-3:HUL.InstRepos:dash.current.terms-of-use\#LAA

\section{Share Your Story}

The Harvard community has made this article openly available.

Please share how this access benefits you. Submit a story.

\section{Accessibility}




\section{University of Chicago Law School Chicago Unbound}

Coase-Sandor Working Paper Series in Law and

Economics

Coase-Sandor Institute for Law and Economics

1996

\section{Social Norms and Social Roles}

Cass R. Sunstein

Follow this and additional works at: http://chicagounbound.uchicago.edu/law_and_economics Part of the Law Commons

\section{Recommended Citation}

Cass R. Sunstein, "Social Norms and Social Roles" (Program in Law and Economics Working Paper No. 36, 1996).

This Working Paper is brought to you for free and open access by the Coase-Sandor Institute for Law and Economics at Chicago Unbound. It has been accepted for inclusion in Coase-Sandor Working Paper Series in Law and Economics by an authorized administrator of Chicago Unbound. For more information, please contact unbound@law.uchicago.edu. 


\section{H ICAG O}

JOHN M. OLIN LAW \& ECONOMICS WORKINg PAPER N 0. 36 (2D SERIES)

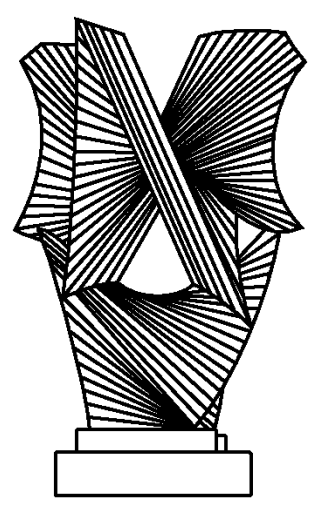

The Coase L ecture

Autumn 1995

Social Norms and Social Rules

Cass R. Sunstein

THE LAW SCHOOL

THE UNIVERSITY OF CHICAGO 
The Coase L ecture Series

The C oase L ecture Series, established in honor of R onald H . C oase, Clifton R. M usser Professor Emeritus of Economics at the University of Chicago Law School, is intended to provide law students and others with an introduction to important techniques and results in law and economics. The lectures presuppose no background in the subject. 


\title{
Social N orms and Social Roles
}

\author{
Cass R. Sunstein*
}

\section{T ales of R ationality and $C_{\text {hoice }}$}

\section{A. U Itimatums and F airness'}

E conomists have invented a game: the ultimatum game. The people who run the game give some money, on a provisional basis, to two players. The first player is instructed to offer some part of the money to the second player. If the second player accepts that amount, he can keep what is offered, and the first player gets to keep the rest. But if the second player rejects the offer, neither player gets anything. Both players are informed that these are the rules. $\mathrm{No}$ bargaining is allowed. U sing standard assumptions about rationality, self-interest, and choice, economists predict that the first player should offer a penny and the second player should accept.

This is not what happens. 0 ffers usually average between $30 \%$ and $40 \%$ of the total. O ffers of less than $20 \%$ are often rejected. 0 ften there is a 50-50 division. These results cut across the level of the stakes and also across diverse cultures.

B. Littering

W hy do people litter? Why do they throw things out instead? Social psychologist Robert Cialdini tried to find out.2 $\mathrm{He}$ placed flyers under the windshield wipers of cars and waited to see what

${ }^{*}$ K arl N . L lewellyn D istinguished Service Professor, L aw School and D epartment of Political Science, University of C hicago. This is a written version of the Coase Lecture, delivered at the University of Chicago on November 28, 1995; it is forthcoming in somewhat different form as a chapter in Cass R. Sunstein, Free M arkets and Social Justice (O xford University Press, 1997).

1 See $C$ amerer and Thaler, U Itimatums, D ictators and M anners, $9 \mathrm{~J}$ Econ Perspectives 209 (1995); $\mathrm{H}$ andbook of Experimental Economics 270, 274-75 282-88, 296-302 (J. Kagel and A. Roth eds. 1995).

2 R. Cialdini, J. Cacioppo, R. Bassett, \& J. M iller, Low-Ball Procedure for Producing Compliance: Commitment Then Cost, $36 \mathrm{~J}$ Personality and Social Psychology 463 (1978). 
drivers would do with them. Cialdini made arrangements so that before reaching their cars, some people would see someone (a Cialdini associate) walk past them, pick up from the street a bag from a fast-food restaurant, and throw it in the trashcan. Of the group who both saw the responsible behavior and noticed the flyers, almost none threw them on the street. In the control experiment, with no one showing responsible behavior, over one-third of the drivers threw the flyers on the street.

W ould it make sense to say that nearly all of the first set of drivers "had a preference for" throwing garbage in the trashcan, whereas merely two-thirds of the second set "had that preference"? This would not exactly be false, but it would not be very illuminating. Whether people put things in a trashcan, or litter instead, is partly a function of social norms and the observed behavior of other people.

\section{Smoking, R ationality, and $R$ ace}

A bout 400,000 A mericans die each year from smoking-related causes. G overnment has tried to reduce smoking through educational campaigns designed to inform people of the risks. D espite this fact, about one million A mericans begin smoking each year, many of them teenagers, and people worry that educational campaigns will succeed, if at all, only with well-educated families. Indeed the government is now initiating a large-scale program to reduce smoking, especially among teenagers.

But consider this. Nationally, $22.9 \%$ of white teenagers smoked in I993, a number that has been basically unchanged in the last decade. But in the same year, only about $4.4 \%$ of A frican-A merican teenagers smoked, a number that is four times smaller than the number a decade before. ${ }^{3} \mathrm{~W}$ hat accounts for this difference? Part of the explanation appears to lie in differing understandings of what is fashionable. And part of that difference may lie in a private antismoking campaign in the A frican-A merican community, symbol-

3 A merican Lung Association, Summary of Trends in Cigarette Smoking (1995). It is notable that the reduction in current smoking among black teenagers was $51 \%$ between 1993 and 1984 , whereas the re duction among black adults was $25.6 \%$, a difference that suggests a substantial effect from social norms among teenagers. 
ized most dramatically by posters in $\mathrm{H}$ arlem subways showing a skeleton resembling the $\mathrm{M}$ arlboro man lighting a cigarette for a black child. The caption reads: "T hey used to make us pick it. N ow they want us to smoke it."

D. Recyding in the $\mathrm{H}$ amptons

In $\mathrm{E}$ ast $\mathrm{H}$ ampton, $\mathrm{N}$ ew Y ork - part of the famous and wealthy "H amptons"- what used to be called the E ast $\mathrm{H}$ ampton D ump is now the East $\mathrm{H}$ ampton Recycling and Disposal Center. At the $\mathrm{E}$ ast $\mathrm{H}$ ampton Recycling and Disposal $\mathrm{C}$ enter, there are separate bins for green glass, clear glass, newspapers, tin cans, paper other than newspaper, and more.

A Imost every day in A ugust, people at the $C$ enter can be found patiently separating their garbage for placement in the relevant bins. Sometimes this takes a long time. The people at the $C$ enter tend to own expensive cars-M ercedes B enz, B M W 's- that are parked near the bins. A s they separate their garbage, they look happy.

E. John Jones

John Jones lives in California. $\mathrm{H}$ ere is a description of some aspects of his behavior.

r. H e buys smoke alarms and installs them in three rooms in his house.

2. He loves chocolate and ice cream, and eats a lot of both. $\mathrm{H} \mathrm{e}$ also eats a fair amount of frozen foods; he makes sure that they are "lean" whenever he has a choice. A ccording to his doctor, he is slightly over his ideal weight.

3. On warm days, he likes to ride his bicycle to and from work, and he enjoys riding his bicycle on busy city streets, even though he has heard about a number of collisions there.

4. $\mathrm{H} \mathrm{e}$ is happily married. $\mathrm{He}$ tries to share the work around the house, but he doesn't much like domestic labor. $\mathrm{H}$ e does less than his share. $\mathrm{H}$ e acknowledges that this is both true and unfair, and he supports many policies that are conventionally described as "feminist."

5. H e buckles his seatbelt whenever he is in a car. $\mathrm{H}$ is own car is a Volvo, and he bought it partly because it is said to be an especially safe car. 
C hicago W orking Paper in $L$ aw and E conomics

6. He is not worried about the risk of an earthquake in California. On some days, he says that he doesn't think that an earthquake is very likely; on other days, he claims to be "fatalistic about earthquakes."

7. He does not recycle. $\mathrm{He}$ considers recycling a personal "irritation." $\mathrm{He}$ is mildly embarrassed about this, but he has not changed his behavior.

8. $\mathrm{H}$ e considers himself an environmentalist; his votes reflect his enthusiasm for environmentalism. $\mathrm{H}$ e supports aggressive regulation designed to protect people from risks to their life and health. In fact he is in favor of mandatory recycling, notwithstanding his own failure to recycle.

9. In his own mind, his resources fall in various mental "compartments." Some money is reserved for retirement; some money is saved for charitable donations. Some money is kept for vacation. Some money is for monthly bills. $\mathrm{H}$ is forms of mental accounting are very diverse. $\mathrm{H}$ e is fully aware of this.

Is J ones inconsistent? Is J ones risk-averse or risk-inclined? W hat is Jones' dollar valuation of a human life, or of his own life?

\section{$E$. The Point of this E ssay}

$M$ y goal in this essay is to challenge some widely held understandings of rationality, choice, and freedom, and to use that challenge to develop some conclusions about human behavior and also the appropriate domain of law. I urge that behavior is pervasively a function of norms; that human norms interact with human goods in surprising ways; that changes in norms might be the best way to improve social well-being; and that government deserves to have, and in any case inevitably does have, a large role in "norm management." F ar too little attention has been played to the place of norms in human behavior and to the control of norms as an instrument of legal policy.

Part of the motivation for this essay is practical. Consider the following tablet:

${ }^{4} \mathrm{M}$ CG innis and Foege, A ctual Causes of D eath in the United States, 270, JAM A 2207 (1993). 
TABLE I

Preventable Risks of Death in the United States

\begin{tabular}{|c|c|c|c|}
\hline Risk & $\begin{array}{c}\text { Percent of } \\
\text { T otal D eaths }\end{array}$ & (R ange) & T otal D eaths/Y ear \\
\hline$\overline{\text { Tobacco }}$ & I9 & I4-I9 & 400,000 \\
\hline D iet/A ctivity & $\mathrm{I} 4$ & $\mathrm{I} 4-27$ & 300,000 \\
\hline Alcohol & 5 & $3-10$ & 100,000 \\
\hline M icrobial & 4 & - & 90,000 \\
\hline T oxic A gents & 3 & $3-6$ & 60,000 \\
\hline Firearms & 2 & - & 35,000 \\
\hline Sexual Behavior & I & - & 30,000 \\
\hline M otor V ehicles & I & - & 25,000 \\
\hline Illicit D rugs & $<\mathrm{I}$ & - & 20,000 \\
\hline
\end{tabular}

W hat is notable is that these risks of death could be much reduced with different social norms. W ith respect to smoking, diet/activity, alcohol, firearms, sexual behavior, motor vehicles, and illicit drugs, current norms are a major problem in the sense that new norms could save lives. ${ }^{5} \mathrm{~A}$ regulatory policy that targets social norms may well be the most effective possible strategy. Social norms are also part and parcel of systems of race and sex equality; if norms would change, existing inequalities would be greatly reduced. ${ }^{6}$ It is thus transparently important to see whether changes in social norms, brought about through law, might operate to save lives and otherwise improve human well-being.

But part of the motivation for this essay is theoretical; it involves a conceptual puzzle. In the last decade there has been an active de bate about whether and to what extent law should respect

$5 \mathrm{~N}$ ote in this regard dramatically shifting social norms with respect to bicycle helmets, as noted in Besides Saving Lives, W earing $\mathrm{A} H$ elmet W hen C ycling is C ool, The W all Street Journal, 9/18/95, at $B_{1}$.

${ }^{6} \mathrm{~F}$ or an especially illuminating discussion, see $\mathrm{O}$ kin, A Clash of Basic Rights? W omen's Human Rights, Identity Formation and Cultural Difference (unpublished manuscript 1995). See also UNDP, H uman D evelopment R eport. 
"preferences." But the term "preferences" is highly ambiguous, and it is not clear what the participants in this debate are actually talking about when they say that "preferences" should or should not be respected by law. When the term is clarified, it becomes clear that the term "preference" can be understood in several different ways, and these differences are too often collapsed. When the idea of a "preference" is unpacked, it becomes clear that it may well be too ambiguous and too coarse-grained to be a foundation for normative or positive work.

M ore particularly, I aim to make a set of conceptual or descriptive points:

I. For many purposes, it would be best to dispense with the idea of "preferences," despite the pervasiveness of that idea in positive social science and in arguments about the appropriate domains of law and the state. In normative work, the idea elides important distinctions among the mental states of human agents. In positive work, the idea tends to disregard contextual factors that produce diverse choices in diverse settings.

2. M any well-known anomalies in choice behavior are best explained by reference to social norms and to the fact that people feel shame when they violate those norms. In fact money itself is not fungible, and this is because of social norms. ${ }^{7}$

3. There is no simple contrast between "rationality" and social norms. Individual rationality is a function of social norms. M any efforts to drive a wedge between the two rest on obscure "state of nature" thinking, that is, on efforts to discern what people would like or prefer if social norms did not exist. Those efforts are doomed to failure. 8

4. Social states are often more fragile than might be supposed, because they depend on social norms to which - and this is the key point- people may not have much allegiance. W hat I will call norm entrepreneurs- people interested in changing social norms-can exploit this fact; if successful, they produce what I will call norm

7 See V. Z elizer, The Social M eaning of M oney (1994).

$8 \mathrm{~A}$ qualification is necessary if the definition of rationality is normative and defended as such. In that case it would be possible to say that a certain norm is irrational because (for example) it makes lives worse. 
bandwagons and norm cascades. Successful law and policy try to take advantage of learning about norms and norm change.

I also aim to make two claims about the appropriate domain of law. T hese claims have a great deal to do with law's expressive function-that is, the function of law in expressing social values and commitments, especially by moving norms in better directions.

I. Individual choices are a function of social norms, social meanings, and social roles, which individual agents may deplore, and over which individual agents have little or no control. N orms can tax or subsidize choice. Collective action-in the form of information campaigns, persuasion, economic incentives, or legal coercion-might be necessary to enable people to change norms that they do not like.

2. Some norms are obstacles to human autonomy and well-being. It is appropriate for law to alter norms if they diminish autonomy by, for example, discouraging people from becoming educated or exposed to diverse conceptions of the good. It is appropriate for law to alter norms if they diminish well-being by, for example, encouraging people to risk their lives by driving very fast, using firearms, or taking dangerous drugs.

\section{F. An Insufficiently Charted D omain}

L ibertarians, some economic analysts of law, and many liberals 9 give inadequate attention to the pervasive functions of social norms, social meanings, and social roles. $O$ ften it is said that in a free society, governments should respect both choices and preferences. But the case for respecting these things depends partly on their genesis, and as I have indicated, the determinants of choices, indeed the meaning of the term "preference," remain most obscure.10 We should agree that social norms play a part in determining choices; that people's choices are a function of their particular social role; and that the social or expressive meaning of acts is an ingredient in

9 The liberal tradition is very complex on this count, and I will not try to sort out its various strands here. I believe that all of the arguments made here fit well within central strands of that tradition.

10 Illuminating discussions include Sen, Behavior and the Concept of a Preference, in A. Sen, Choice, W elfare, and M easurement (I982); E. A nderson, Value in E thics and E conomics ( 1993 ). 
choice. ${ }^{11} \mathrm{~W}$ e should try to see whether social norms, social roles, and social meaning can be obstacles to human well-being, and whether something might be done to change them, even if people are making "choices," even if there is neither force nor fraud, and whether or not there is "harm to others."

O ne of my central points here is that individual agents have little control over social norms, social meanings, and social roles, even when they wish these to be very different from what they are.12 This is not an argument against norms, meanings and roles. $\mathrm{H}$ uman beings can live, and human liberty can exist, only within a system of norms, meanings, and roles; but in any particular form, these things can impose severe restrictions on well-being and autonomy. A gents who seek to make changes face a collective action problem.

For example, it is impossible for an individual to say whether the act of smoking seems daring, or the act of recycling seems exotic, or the act of rejecting sexual harassment seems extreme and humorless. This is so even though the relevant norms greatly influence behavior. If, for example, smokers seem like pitiful dupes rather than exciting daredevils, the incidence of smoking will go down. If people who fail to recycle are seen as oddballs, more people will recycle. If the role of secretary is not connected with susceptibility to unwanted sexual attention, there will be less unwanted sexual attention. The point very much bears on current public disputes. If single parenthood is stigmatized, and if lesbian couples are treated just as "couples," social practices will change accordingly. Thus government might try to inculcate or to remove shame, fear of which can be a powerful deterrent to behavior.

Government cannot avoid affecting social norms. A market economy will, for example, have predictable effects on norms, and historically it has been justified on just this ground, as a way of softening social divisions by allowing people to interact with one an-

11 See the especially instructive discussion in Lawrence Lessig, The Regulation of Social M eaning, 62 U Chi L Rev 943 (1995); though I have referred to this paper at various points, my presentation here owes a general debt to L essig's argument and in particular to his emphasis on the collective action presented by social meanings.

12 See id. 
other on a mutually beneficial basis. ${ }^{13} \mathrm{~A}$ good deal of governmental action is designed to change norms, meaning, or role, and in that way to increase the individual benefits or decrease the individual costs associated with certain acts. In fact social norms can operate as taxes on or as subsidies to behavior.

M ore particularly, I hope to draw attention to the fact that people's conception of appropriate action and even of their "interest" is very much a function of the particular social role in which they find themselves. This is true of (for example) judges, lawyers, doctors, parents, children, waiters, wives, husbands, colleagues, friends, and law school deans. A ttention to the place of social role shows that for many purposes, the contrast between "rationality" and social norms is unhel pful. W hat is rational for an agent is a function of, and mediated by, social roles and associated norms. ${ }^{14}$ And when social norms appear not to be present, it is only because they are so taken for granted that they seem invisible.

At the same time, norms and roles-as taxes or subsidies-create a division between the judgments and desires that are displayed publicly and the judgments and desires that would be displayed without current norms and roles. ${ }^{15}$ People's private judgments and desires diverge greatly from public appearances. For this reason current social states can be far more fragile than is generally thought-as small shocks to publicly endorsed norms and roles decrease the cost of displaying deviant norms, and rapidly bring about large-scale changes in publicly displayed judgments and desires. H ence societies experience norm bandwagons and norm cascades. Norm bandwagons occur when the lowered cost of expressing new norms encourages an ever-increasing number of people to reject previously popular norms, to a "tipping point" where it is adherence to the old norms that produces social disapproval. $\mathrm{N}$ orm cascades occur when societies are presented with rapid shifts

13 See A. H irschman, Passions and Interests ( 1977 ).

14 See the discussion of conflicts between social norms and the purchase of life insurance in V. Zelizer, M orals and M arkets: The $D$ evelopment of Life Insurance in the U nited States (I983).

15 See T. Kuran, Private T ruths, Public L ies ( 1995 ). 
toward new norms. ${ }^{16}$ Something of this kind happened with the attack on apartheid in South A frica, the fall of Communism, the election of Ronald Reagan, the rise of the feminist movement, and the current assault on affirmative action.

To spell out the most general point emerging from the discussion: The notion of "a preference" can be deeply confusing and in many of its uses, it impairs both positive and normative analysis of law. In its standard form, a preference is supposed to be something that lies behind choices and that is more abstract and general than choices are. ${ }^{17}$ But what lies behind choices is not a thing but an unruly amalgam of things ${ }^{18}$-aspirations, tastes, physical states, responses to existing roles and norms, values, judgments, emotions, drives, beliefs, whims-and the interaction of these forces will produce outcomes of a particular sort in accordance with the particular context. Hence we might say that preferences are constructed, rather than elicited, by social situations, ${ }^{19}$ in the sense that they are very much a function of the setting and the prevailing norms.

I will be emphasizing the highly contextual nature of choice and hence the fine-grained nature of anything capable of being de-

${ }^{16} \mathrm{Cf}$. Bikchandani et al., A Theory of Fads, Fashions, Custom, and Cultural C hanges as Informational Cascades, roo J Polit E con 992 (I992); Zelizer, Pricing the Priceless Child: The Changing Social Value of Children (1987).

17 This is the idea behind much of $G$ ary Becker's work. See, e.g., G. Becker, A T reatise on the Family ( $2 \mathrm{~d}$ ed. I993). F or Becker's most recent statement, see the forthcoming A ccounting for Taste.

18 See Gary Becker, The Economic W ay of Looking at Life, University of C hicago, Law \& E conomics W orking Paper $\mathrm{N} \mathrm{O}$. I2, at is (1993): "A $n$ important step in extending the traditional analysis of individual rational choice is to incorporate into the theory a much richer class of attitudes, preferences, and calculations."

${ }^{19} \mathrm{Cf}$. Slovic, The Construction of Preference, 5o A m. Psych. 364 (1995). I mean to use the idea of construction somewhat more broadly than does Slovic. N ote in this connection the striking study by Ross and Samuels, showing that people cooperate when a certain game is denominated "C ooperation," but not when the same game is denominated, "W all Street." See Ross \& Samuels, The Predictive Power of Personal Reputation (unpublished manuscript 1993). 
scribed as a person's "preferences." Some people think that the notion of "preference" can be identified with "rational self-interest" in a way that abstracts from social roles and norms. As the examples above suggest, the attempt at abstraction makes positive work treacherous; social norms are very much a part of what underlies choice. If preferences are understood to be bound up with social norms - with the wellsprings of shame and pride- positive analysis will be more accurate; but we will have to disaggregate the various wellsprings of choice. This point bears on the appropriate content of law and on the vexing question of paternalism; it also shows that important collective action problems, calling for a legal response, can appear in some unusual settings.

\section{D efinitions and C oncepts}

\section{A. N orms}

The term "social norms" might be understood in many different ways. For present purposes the differences among the possible definitions are not very important, and we can rely on conventional understandings. If a definition is thought necessary, we might, very roughly, understand "norms" to be social attitudes of approval and disapproval, specifying what ought to be done and what ought not to be done. There are social norms about littering, dating, smoking, singing, when to stand, when to sit, when to show anger, when, how, and with whom to express affection, when to talk, when to listen, when to discuss personal matters, when to use contractions. In fact there are social norms about nearly every aspect of human behavior.

"It isn't done" is a frequent reaction to certain conduct-even though the relevant "it" is indeed done. These attitudes span an exceptionally wide range. They may or may not begin or maintain themselves as a result of reflective judgments. Social norms may or may not promote liberty and well-being; they may or may not be easily malleable or go very deep into people's understandings. A social norm can count as such whether or not people have thought deeply about whether it makes sense. Some norms set good manners, for example about how to hold one's fork; others reflect morally abhorrent views, as in the taboo on interracial relations; others reflect 
hard-won moral commitments, as in the taboo on racial epithets. Sometimes norms are codified in law.

Social norms are enforced through social sanctions; these sanctions create a range of unpleasant (but sometimes pleasant) emotional states in the minds of people who have violated them. If someone behaves in a way inconsistent with social norms, public disapproval may produce shame and a desire to hide. Sometimes the unpleasant feelings brought about by violations of social norms are intense, and the social consequences of these feelings, and of anticipating them, can be substantial. ${ }^{20}$

From these points we might conclude that choice among options is a function not only of (a) the intrinsic value of the option-a book, a job, a drink-but also of (b) the reputational benefit or cost of the choice and also of (c) the effects of the choice on one's self-conception. Someone may watch a television show on public broadcasting not only because it is enjoyable, but also because there are reputational advantages from doing so and advantages as well from the standpoint of promoting one's self-conception. Social norms are a key determinant in reputational benefit or cost. They can much affect self-conception as well. $\mathrm{H}$ ence changes in social norms can affect choices if intrinsic value is held constant, by altering the effects of reputational incentives and consequences for self-conception.

In a way social norms reduce freedom, understood very broadly as the power to do whatever one would like to do. ${ }^{21}$ C ertainly norms stop people from doing things that (if the norms were different) they would like to do, and certainly people would sometimes like the norms to change. But it would be quite ludicrous to deplore social norms, to see them only as constraints on freedom, or to wish them

20 The persistent urge to conform to social norms has been demonstrated in a good deal of work in social psychology. The classic study is A sch, E ffects of $G$ roup Pressure upon the $M$ odification and $D$ istortion of Judgments, in G roups, L eadership, and M en (H. G uetzkow ed. I963).

21 I do not mean to endorse this conception of freedom as a normative ideal. $M$ any unobjectionable things-like speed limit laws or high prices - reduce freedom, thus understood. I seek only to draw attention to the fact that norms can constrain behavior and choice even though some or many people would like them to be otherwise. 
to disappear. In fact norms make freedom possible. Social life is not possible - not even imaginable - without them..$^{22}$ In the absence of social norms, we would be unable to understand one another.23 Social norms are thus facilitative as well as constraining. If everyone knows the norms concerning a raised voice, or wearing bluejeans, then people can raise their voices, or wear bluejeans, without having to decide what these actions mean.

There is a further and, for present purposes, an especially important point. Good social norms solve collective action problems, by encouraging people to do useful things that they would not do without the relevant norms. ${ }^{24} \mathrm{C}$ onsider voting, littering, behaving courteously, keeping promises, cleaning up after one's dog, writing tenure letters, and doing one's share of administrative work. W ithout social norms, coercion or economic incentives- perhaps with large financial investments- would be required to ensure that collective action problems are solved. A nd when norms are inadequate, or start to disintegrate, society can encounter large difficulties and even collapse.

On the other hand, some people like to incur the disapproval that follows norm-violation, and hence some people like to "flout convention" by rejecting prevailing norms- by, for example, dating someone of another race, smoking, playing loud music in public, or wearing unusual clothes. Of course people who violate generally held social norms might be behaving consistently with particular norms in a relevant subculture. (H ence those who reject generally held norms may be the most committed of conformists.)

22 T his is a theme of Jon E Ister, The C ement of Society (I993).

$23 \mathrm{H}$ ence cross-cultural understandings are sometimes made difficult by the fact that social norms are different in different cultures, so that meanings have to be translated, and people may be unaware of that fact. Consider the example of whistling at sporting events.

24 See $E$. Ullmann-M argalit, The E mergence of $\mathrm{N}$ orms (1979). R. Ellickson, O rder W ithout Law (I993), is an important discussion of how norms produce social order, and solve collective action problems, in the absence of legal constraints. But norm changes do not produce Pareto improvements; there are losers as well as winners. $M$ oreover, there is a crucial question about which norms are taken as given, and which are put up for grabs, in the sort of analysis that celebrates certain norms as solving collective action problems. See TAN infra. 
The fact that some people like to reject social norms is highly relevant to law. For example, a serious problem with legal efforts to inculcate social norms is that the source of the effort may be disqualifying. If $\mathrm{N}$ ancy Reagan tells teenagers to "just say no" to drugs, many teenagers may think that it is very good to say "yes." It is said that propaganda efforts in the former Soviet U nion failed simply because the source of the propaganda was not trusted; hence the government's effort to inculcate norms of its choosing fell on deaf ears. These points bear on the regulation of risk, particularly in the areas of teenage smoking and potentially dangerous sexual activity. E fforts by private or public authorities to stigmatize certain acts may have the opposite effect.

The fact that norms are contested can lead to the creation of many diverse norm communities. People who are dissatisfied with prevailing norms can vote with their feet, using the power of "exit" to find groups built on more congenial norms. M any A merican high schools reflect this phenomenon, as students find groups that are defined in a relatively crisp way, and as groups intermingle only on occasion. $\mathrm{O} n$ the other hand, it can be very costly to exit from the norm community in which one finds oneself, and the fact that one has been raised in that community may make other options seem unthinkable even though they might be much better.

Strange as it may seem, social norms mean that money itself is not fungible.25 The uses of money, and the place of different "kinds" of money, are pervasively affected by social norms. People put money in different mental compartments and act accordingly. Some money is specially reserved for the support of children. Some money is for gifts; some is for one's own special fun. Some money is to be given to charities. Some money is for a rainy day. If you receive a fee for a lecture, or a small amount from the lottery, you may use it for a special dinner.

Social norms make for qualitative differences among human goods, ${ }^{26}$ and these qualitative differences are matched by ingenious mental operations involving qualitative differences among different "kinds" of money. Thus a study of practices in O range County, California, reports that residents keep "a variety of domestic 'cash

25 See V. Z elizer, The Social M eaning of M oney (1994).

26 See $E$. A nderson, Value in Ethics and E conomics (I993). 
stashes'-generally one in the billfold of each adult, children's allowances and piggy banks, a petty cash fund in a teapot-equivalent, a dish of change for parking meters or laundry - or 'banked stashes of money,' including Christmas club savings and accounts designated for special expenditures as property or other taxes, vacations, or home and car insurance payments."27

In short, there are complex procedures of "mental accounting" in which money that falls in certain compartments is assessed only in terms of its particular intended uses, and not compared with money that has been placed in different mental compartments. ${ }^{28} \mathrm{~W}$ e cannot understand the uses of money itself without understanding the role of social norms. Social theorists have often feared that the use of money would "flatten" social life, above all by erasing qualitative distinctions; but it would be more accurate to report that social life, pervaded as it is by social norms, has "unflattened" money, by insisting on and enforcing qualitative distinctions. ${ }^{29}$ "There is no single, uniform, generalized money, but multiple monies: people earmark different currencies for many or perhaps all types of social interactions... [a]nd people will in fact respond with anger, shock, or ridicule to the 'misuse' of monies for the wrong circumstances or social relations...." 30 Thus norms and law barring the use of money in certain contexts are complemented by norms barring the use of certain money (say, retirement money) for certain purposes (say, gambling or vacation).

\section{B. Roles}

I. In General. M any norms are intensely role-specific. Consider the following social roles: doctor, employee, waiter, law school dean, wife, friend, pet-owner, colleague, student. E ach of these roles is accompanied by a remarkably complex network of appropriate norms. The network is not easily reduced to rules, but people know, often very well, what they are. If you are a waiter, and treat your restaurant's patrons the way you treat your friends, you will probably not

27 Id. at 5, quoting Jean $L$ ave, Cognition in Practice $\mathrm{I}_{32-}-33$ (I988).

28 See Richard Thaler, $M$ ental A ccounting $M$ atters (unpublished manuscript, University of Chicago Business School I995).

29 See id. for an impressive argument to this effect.

30 Z elizer, supra, at I8- I9. 
be a waiter very long (except perhaps in C alifornia). If you are a student, and treat a teacher as if he were your employee at the local factory, you will be perceived as misbehaving very badly. If you treat a colleague in the way you treat your doctor, you will undoubtedly seem quite odd. If you treat a friend the way doctors treat patients, or lawyers treat clients, you probably won't have many friends. People rapidly internalize social norms about what their roles entail. Violations of role-specific norms can seem jarring and produce prompt social punishment (or reward).

Roles are accompanied by a wide range of included and excluded reasons for action. In your capacity as lawyer, you can act only on the basis of certain reasons. For example, you may reveal something told to you in confidence only to prevent a crime; you cannot breach a confidence on the ground that it would be economically profitable to do so. In your capacity as teacher of English, you may not rank students on the basis of family connections, looks, or athletic ability. In your capacity as judge, you may look only at a restricted set of considerations, a set far more restricted than those you may examine if you are a legislator. Confusion of role- is X speaking as a friend or as a colleague? is the judge a closet legislator? what exactly is my relationship to my employer? - can cause uncertainty, awkwardness, or much worse.

2. R oles and $\mathrm{F}$ redom. A re social roles an obstacle to freedom? I $\mathrm{n}$ a way the answer is yes, since people would often like to do things that their role forbids, and since people would often like to change the nature of their roles. But this would be a far too simple conclusion. W ithout roles, life would be very hard to negotiate. Like social norms, social roles are facilitating as well as constraining.

Of course some of the norms associated with certain social roles are silly or even oppressive, and some people deplore them for this reason. W hat can they do? L arge-scale changes in social roles normally require collective action, whether private or public-a point with considerable importance for those interested in the appropriate domain of law. But sometimes individual people act in ways inconsistent with their roles precisely in order to draw attention to their silly or oppressive character. Thus a slave in the pre-Civil W ar south might decide not to act deferentially; a student might raise his voice against an abusive teacher; a woman in an unequal society might 
insist that domestic labor should be shared; a homosexual man might "flaunt it"; a teacher in business school might wear bluejeans.

There are many possible reasons for rejecting prevailing norms with respect to role. Some people depart from the prevailing norm because of their reflective judgments. Such people think, on reflection, that the norm is too silly or too unworthy to affect behavior, or that relevant roles diminish autonomy or well-being. M arrying someone of a different race may reflect this judgment; sharing domestic labor on an equal basis almost certainly does. ${ }^{31}$ In other cases, the departure simply expresses defiance, and the real desire is to flout convention, whatever the norm is. M any apparently odd practices involving dress and manners are rooted in this phenomenon; some people find defiance an intrinsic good, and what they are defying is more or less incidental. In still other cases, the departure is the expression of an individual desire or taste, which the person would pursue whether or not it is inconsistent with social roles and accompanying norms. Consider the view that Coca-C ola actually is better than all other drinks, a view that might be reflected in unconventional drink selections in many imaginable places.

3. Roles and L aw. Prevailing roles and norms can be fortified by legal requirements; they may even owe their existence to law. $L$ aw is frequently an effort to prescribe roles. There are many specific legal provisions for people occupying different roles-parents, spouses, employers, employees, home-owners, nuclear power plant operators, animal owners, doctors, stock brokers, landlords, automobile sellers, and others. By prescribing appropriate behavior, law can help constitute the relevant social roles. M uch of the law relating to families, employer-employee relations, and professional obligations has this feature. In fact many roles seem "natural" even though they owe their origin to social and even legal conventions.

0 ften law tries to redefine roles. In recent years, this has happened with respect to the roles of employee, husband, father, disabled person, and judge. Thus, for example, the law has said that husbands may not rape their wives; that absent fathers owe duties of support to their children; that disabled people have certain rights of access to the workplace.

31 See S. O kin, Justice, G ender, and the Family (1989). 
L aw's pervasive attention to role shows (yet again) the poverty of the familiar idea that "efficiency" and "distribution" exhaust the concerns of the state. Sometimes society and law revisit a currently conceived role for reasons that have nothing to do with either efficiency or distribution. People occupying a certain role may, for example, not be treated with appropriate respect; they may not receive love and affection; or they may not be targets of (deserved) shame.

4. Citizens and Consumers. Of course each of us occupies many different roles, and there is much to be said about the constraints imposed by these diverse roles. But for present purposes, an especially important and pervasive difference involves the relationship between citizen and consumer.

R eturn to John Jones in the fifth tale above. The example shows that in your capacity as a citizen, you might urge a result-with respect to, say, the duties of polluters or commercial broadcasters- that is quite different from what you seek through your market behavior in your capacity as a consumer. A cting as citizens, many people try to change social practices, and they often try to do this by changing social norms associated with a particular role. Sometimes these efforts are a function of the role of citizen and associated norms. In their private capacity-as consumers, employers, or family members- people may do what they know, on balance, to be unjust, and as citizens, they may support measures that better reflect their convictions. Sometimes efforts to change norms and roles reflect an understanding that human beings are selfish or have weakness of will, and that some measures should be taken to ensure behavior that, on reflection, we would like to follow. 32

In addition, citizens do or say things just because of existing social norms, which impose sanctions on publicly expressed dissident behavior or judgments; in their private capacity, people may be freer to do or say as they wish. In all cases the difference is connected to the fact that a citizen is helping to make a judgment not simply for himself but for a collectivity. In this sense there are important contextual differences between market behavior and voting behavior. The former does not affect the collectivity in the same way, and hence those concerned, for example, to protect the environment

32 See J. E Ister, Ulysses and the Sirens (1983); S. H olmes, Passions and Constraint (1995). 
may believe that their own behavior is largely irrelevant, whereas laws can make a great deal of difference. L argely for this reason, the role of citizen is accompanied by norms that can discourage selfishness and encourage attention to the public good. 33

In fact many efforts to change law are at least partly an outgrowth of the difference between citizens and consumers. 34 Consider laws outlawing sexual harassment, providing incentives to share domestic labor, 35 or granting workers a right to unionize. It should be clear that in such cases, there is no simple relationship among choices, preferences, norms, and roles. There may be conflict or tension between two or more of these.

\section{M eaning}

By "meaning," I refer to the expressive dimension of conduct (not excluding speech) in the relevant community. ${ }^{36} \mathrm{~T}$ he expressive dimension involves the attitudes and commitments that the conduct signals. A complex body of first amendment doctrine deals with the problem of "expressive conduct," that is, acts that carry an expressive purpose and effect, such as flag-burning, draftcard-burning, sleeping in parks. But most conduct has an expressive function- not in the sense that the actor necessarily intends to communicate a message, but in the sense that people will take the conduct to be expressing certain attitudes and commitments.

Consider some examples. If I light up a cigarette, I will, in certain parts of the United States, be signaling something relatively precise and very bad about myself, my self-conception, and my concern for others. In other parts of the U nited States, the signals are very different. In F rance, a smoker gives still different signals. If you fail to attend church - or if you do attend church, and tell everyone about it-your act will have particular meanings, and these have ev-

33 I am describing a possibility, not a certainty. Political behavior is very often selfish.

${ }^{34}$ See Sen, Environmental E valuation and Social C hoice: Contingent $V$ aluation and the Market Analogy, 46 Japanese Economic Review 23 (1995)(distinguishing consumer's willingness to pay from citizen judgments).

35 See 0 kin, supra note, at $134-69$.

36 See L essig, supra note. 
erything to do with the community in which you find yourself. If I decide not to get married, or not to have children, my act will convey a restricted range of possible meanings, and I will not have much control over those meanings. (If I were a woman, my decisions to this effect would have a quite different set of meanings. The meaning of a woman's not marrying or having children is quite different from a man's.)

Language also has social meanings, extending far beyond the words themselves and reflected in the attitudes and commitments signaled by how people talk. Context determines those meanings. The words, "You look great today," can have many different possible social meanings: consider their use from a mother to a fifteen year old daughter, from a male employer to a female employee, from a doctor to a convalescent patient, from a homosexual male student to a male classmate. If you refer to women as "ladies," you are also making (whatever your intentions) a certain set of statements about yourself and about your views on gender issues. A description of certain A mericans as "blacks" will have a different meaning in 1996 (after the adoption of the term "A frican-A merican") from what it was in, say, 1976.

A s with social norms and social roles, the social meanings of acts are something about which individuals can do relatively little (most of the time). 37 If a lawyer drives a $\mathrm{H}$ arley-D avidson motorcycle to W all Street, his own attitude toward his act will have little relation to what other people take his act to mean. If a nonsmoker asks someone not to smoke, the social meaning of the act will be quite different in $\mathrm{N}$ ew Y ork in 1995 from what it was in the same city in I965, and different as well from what it is in G ermany in 1995. This is a pervasive characteristic of social meanings. If you lived in a society of vegetarians, the act of eating meat-at, let us suppose, specially designated animal flesh restaurants-would be very different from what it is is a society of meat-eaters; and if you lived in a society of vegetarians, you might well choose not to eat meat. The meanings of actions are set by forces that are emphatically human but that are largely outside of the control of the individual agent.

37 See L essig, supra note, for discussion of the collective action problem. 
On the other hand, there are contexts in which a person or a small group of people may make inroads on social meanings. In a household, a woman may be able to alter, a little or a lot, the social meaning to her family of her refusal to do dishes or to make dinner, or her decision to go out with colleagues at night. But the most entrenched social meanings are-by definition-not movable without concerted action on the part of many people. $\mathrm{H}$ ence private groups often attempt to bring about changes in meanings and the norms that produce them. Religious organizations, feminist groups, animal rights activists, groups challenging "political correctness," are prominent recent examples. $\mathrm{O}$ ften they have been highly successful; sometimes they produce norm cascades.

$M$ any roles are ascriptive and not chosen, even in postfeudal societies. W e cannot fully control the roles in which we find ourselves. To be sure, people have power to assume or not to assume some roles. Y ou can decide whether to be a spouse, a parent, a teacher, a dean, and so forth. A nd within limits, you can decide what it means to be any of these things; people can certainly alter the roles associated with parent, wife, and husband, even if they cannot do a great deal about the meanings associated with their choices. But many roles are assigned rather than voluntarily assumed-child, man, A frican-A merican, old person, short person, and more. A role that is assigned might be described as a status, a distinctive kind of role that, if surrounded by objectionable norms, raises special problems (see the discussion of caste below). And many roles cannot easily be rejected in most societies-driver, employee, student, citizen, family member.

\section{Beliefs About $F$ acts}

Choices, meaning, role, and norms are commonly based on beliefs about relevant facts. In fact beliefs about facts help generate all of these things. Someone may believe, for example, that cigarette smoking is not dangerous, and he may smoke partly for that reason. If he really believed that smoking was dangerous, perhaps he would not smoke. C hoices are pervasively a function of beliefs. The same is true for social norms. Consider the dramatic recent shifts with respect to social norms governing cigarette smoking. Such norms have a great deal to do with prevailing beliefs about whether smoking 
causes harm to nonsmokers. W hen the belief shifts, the norm shifts as well.

Norms about behavior are interpenetrated with beliefs about harm and risk. Thus many religiously-grounded norms about personal cleanliness and hygiene often owe their origins to beliefs about what is healthy; but the norms often outstrip the beliefs and receive a kind of moral grounding that is not simply reducible to an instrumental judgment about likely risks. W hen someone violates a norm relating to hygiene, people's reaction is different-more stern and more deeply moralized-than it would be if the reaction were based solely on the incremental increase in risk.

There are complex interactions between understandings of facts and social roles. Certainly beliefs about facts help generate roles. Thus beliefs about natural differences between men and women, or blacks and whites, affect social understandings about the appropriate roles of men and women or blacks and whites. W hen people see that apparent differences between social groups are not grounded in fact, the roles associated with group members may shift accordingly. Thus attacks on claimed natural differences have affected perceptions of appropriate role. But the converse is also true: Understandings of facts may be a function of roles and accompanying norms. There are complex scientific literatures on the differences between men and women; much of the relevant work, even in its most scientific forms, rests palpably on conceptions of roles and of surrounding norms.

Judgments about fact are similarly entangled with social norms. W hen most people smoke, it is hard for most people to believe that smoking is dangerous. The norm affects the belief, just as the belief affects the norm. In fact norms and judgments about risk are hard to separate.

\section{E. Divisions in the Self and Norm Bandwagons}

I have noted that social norms can make people act and talk publicly in ways that are different from how they actually think, or from how they act and talk privately. People comply with norms that they wish were otherwise or even despise. Under the apartheid regime in South Africa, public criticism of apartheid-at least within South Africa- much understated private opposition to 
apartheid. The same is truth for $\mathrm{C}$ ommunist regimes. ${ }^{38}$ In a social group that punishes atheists or agnostics, few people may confess their uncertainty about whether God exists; in a group of atheists, few people may talk about their religious faith. E ven in democracies, the deterrent effect of social norms on acts and beliefs creates a sharp disjunction between public acts (including speech) and private thought. $\mathrm{H}$ ence a state of affairs may persist even though there is widespread opposition to it. And eventually the norms may affect private thought itself.

Political actors might be able to exploit this disjunction in order to bring about large-scale social change. In fact many political participants can be described as norm entrepreneurs. Individuals who are in favor of changes in norms face a free rider problem. Political actors can exploit their dissatisfaction with existing norms by (a) signaling their own commitment to change, (b) creating coalitions, and (c) making defiance of the norms less costly. W hen the free rider problem begins to be solved, through reducing the cost of acting inconsistently with prevailing norms, the private thoughts will be stated publicly, and things can shift very quickly. Something of this sort happened in both South A frica and E astern Europe, producing more rapid and more peaceful changes that anyone anticipated. Part of the reason is that hostility to the regimes was widespread and intense- but inconsistent with existing social norms and hence mostly invisible and thus much underestimated. W hen the norms began to collapse, the regimes collapsed too.

The point bears on norm bandwagons. People may publicly support an existing norm not because they are genuinely committed to it, but because they fear social sanctions. A s I have said, there is a bandwagon effect when those sanctions diminish or disappear, as many people join the group opposing the existing norm and urging a new one. The result can be astonishingly rapid change. ${ }^{39} \mathrm{~A} n$ effect of this kind occurred with two opposing and recent move-

38 See T. Kuran, supra note, on which I draw for the discussion in this paragraph.

39 Id. at 288 ("A specific law, regulation, policy, norm, or custom can be abruptly abandoned when people who have helped sustain it suddenly discover a common desire for change.") 
ments - the feminist movement and the recent opposition to "political correctness" in the university.

\section{C hoices and Preferences}

If we attend to the functions of norms, meaning, and role, how will we understand the relationship between choices and preferences? A $n$ initial problem is that the notion of a "preference" is quite ambiguous. Suppose someone takes a job as a welder, recycles newspapers, or buys aspirin rather than chocolate bars. W hen we say that someone "prefers" to do as he chose, what exactly do we mean? There are two major possibilities. A ttention to the place of norms, meanings, and roles complicates both of them.

\section{A. Preferences As C hoices}

The idea of a "preference" might be understood as simply a choice, as in the idea, influential within economics, of the "revealed preference." On this view, preferences are choices. This approach seems promising, because it makes it unnecessary to inquire into the mental states that accompany choices. Perhaps we can work from behavior alone. If, however, this is what we are doing, it is unnecessary and perhaps misleading to use the notion of a "preference," which seems to be intended to explain or to back something called choices. If we are really talking about choices, we can dispense with the idea of preferences entirely. W e will have a list of choices and should speak only in terms of that list.

Perhaps this is merely a semantic quibble. Perhaps social theorists can work with the list for positive or normative purposes. But if they are really working just with choices, they will encounter many problems. Choices are inarticulate, and hence imperfect predictors of behavior, without an account of what lies behind them. 40 From the bare fact of (particular) choices, it is not always possible to make robust claims about future choices. Because of the function of norms, meanings, and role, even the weakest axioms of revealed preference theory can fail. John Jones, in the fifth tale above, pre-

40 See Sen, Internal Consistency of Choice, 6r Econometrica 495 (1993); E. A ronson, The Social A nimal (8th ed. 1995); T versky \& Simonson, Context-D ependent Preferences, $39 \mathrm{M}$ anagement Science II79 (1993). 
sents an illustration; his particular choices do not allow observers to offer general predictions. But for the present let us take a simpler example. If Jones prefers $X$ over $Y$, we might think that he will not prefer $Y$ over $X$ or $Z$; the introduction of the third alternative, $Z$, ought not to change Jones' preferences for $X$ over $Y$. A fter all, Jones prefers $X$ to $Y$, and he would have to be an odd person to prefer $Y$ to $X$ simply because of the introduction of $Z$.

B ut we can readily imagine cases in which the new alternative $Z$ has precisely this effect. Jones might, for example, al ways select the second largest piece of cake, or he might want to be a person of relative moderation. E mpirical work has encountered an effect called "extremeness aversion," in which people make choices that avoid the extremes. ${ }^{41}$ Extremeness aversion is a product of social norms. People are generally taught to avoid extremes, and people who make extreme choices seem like malcontents, oddballs, or (never a word of praise) extremists. There are many examples. A voter might, for example, choose a Republican candidate over a D emocratic candidate; but the introduction of some third candidate, say Ross Perot, may change the underlying choice, because it makes some new characteristic salient to voters, 42 or because it shifts the outcome produced by the decision, making it moderate where it would otherwise be extreme.

M ore broadly, choices are a function of prevailing social meanings and roles, which can bring into effect a wide range of relevant norms. If you are in a certain social group, you may well choose a drink of brandy or wine over Coca-Cola simply because of local practices. The choice of $\mathrm{C}$ oca-C ola may signal excessive informality, an unwillingness to unwind and enjoy oneself, or even disrespect. I n a different group, your choice may be different (and all this regardless of what you would choose if you were in your house alone). Y ou may purchase an A merican car, or display the flag on July 4 , because of existing norms in your community. Perhaps your purchase of a

41 See Amos Tversky \& Itamar Simonson, Context-D ependent Preferences, $39 \mathrm{M}$ anagement Science iI79 (I993).

42 Cf. L eland, G eneralized Similarity Judgments: A n Alternative Explanation for Choice A nomalies, $9 \mathrm{~J}$ Risk and Uncertainty I5I (1994). See also Simonson and T versky, Choice in Context, $29 \mathrm{~J}$ M arketing Research 28I (1992). 
non-A merican car would signal a lack of patriotism; perhaps your failure to display the flag would be taken as a political protest, whether or not you meant it that way. If you run a local television station, your decision whether to allow violent programming is very much a function of prevailing norms, even if such programming would attract a large audience.

These points suggest that to explain or predict behavior, it is important not only to know about choices but also to have some account of what underlies choices, or of what choices are for, and in this way to introduce an account of motivation. ${ }^{43} \mathrm{H}$ ere social norms, meanings, and roles will be crucial. And if this is right, it is impossible to explain behavior by reference to choices, without using the very apparatus that the "revealed preference" idea was intended to eliminate. N ormative arguments on the basis of choices alone ${ }^{44}$ will also run into serious trouble. Choices do not suggest acontextual valuation of social goods, and thus even if we want to respect people's valuations, we will have to look not at but behind choices.

\section{B. Preferences B ehind Choices}

$L$ et us turn, then, to another and more promising conception of a "preference." The term is often meant to refer not to choices themselves, but to something that lies behind and accounts for choices. ${ }^{45}$ This idea has obvious advantages. It seeks to provide the motivational story on which choices are by themselves inarticulate, and if the motivational story is uncovered, positive work should be possible. And if we can identify what lies behind choices, perhaps we can get a sense of people's own conception of what promotes their well-being, and this is surely relevant for purposes of both ethics and politics.

But this idea introduces difficulties of its own-indeed, the difficulties that the "revealed preference" notion was intended to overcome. Recall John Jones, the protagonist of the fifth tale above. $\mathrm{C}$ an we provide an account of Jones' motivation or "preferences"? No simple answer would make sense. Several possibilities do present

43 See Sen, E conometrica, supra note.

44 See W . K ip V iscusi, Fatal T radeoffs (1993).

45 See George Stigler \& Gary Becker, De Gustibus Non Est Disputandum, 67 A m. E con. Rev. 76 (1977). 
themselves. F rom the fact that Jones pays a certain premium for automobile safety, we might judge that he is risk-averse and we might even attempt to generate numbers capturing his own conception of the value of his life. But when it comes to bicycle riding, Jones is somewhat reckless. And in his capacity as voter, Jones' valuations appear still more complex. To get an account of his motivation, we need to know many details- something like a personality profile.

The point raises some larger issues. If we think of a preference as something that lies behind choice, what is it exactly? Plainly it is a disposition or a mental state of some kind. And plainly people do have dispositions of various sorts. But internal mental states can be extraordinarily complex. People's decisions are based on a complex of whims, responses to norms, second-order preferences, aspirations, judgments, emotions, drives of various kinds, conceptions of role, and more, with all these producing particular results depending on the context. W hat lies behind a choice in one setting may be quite different from what lies behind a choice in a different time and place.

In this light, it can be hard to make predictions about individuals or groups without knowing a great deal. Of course the value of positive work lies in what the evidence shows. Of course there are regularities in people's behavior, and these regularities can be connected to people's dispositions. But general dispositions of various kinds- to avoid extremes, to comply with norms, to drink beer rather than wine- manifest themselves in particular choices only in accordance with context. No simple thing called a "preference" accounts for choice. Preferences are not the building-blocks for a theory of decision; whatever we call a "preference" needs to be further unpacked.

Shifting from positive to normative, we can see that the complexity of mental states also makes it hard for governments to know how to respond to people's choices. Choices depend on norms that people may not endorse on reflection. Collective efforts to discourage damaging or risky behavior, or to encourage norms that promote well-being or solve collective action problems, might well be consistent with people's underlying aspirations and judgments.

\section{Complex Preferences}

From all this we might conclude that for many purposes, the whole idea of "a preference" is confused and misleading, because it is 
ambiguous between choices and underlying psychological forces, and because the mental operations that produce choices are a function of a great many factors. For many purposes, it might well be best to dispense altogether with the idea of preference and to work instead with choices on the one hand and with complex and somewhat unruly mental states on the other-or to relate choices to more concrete influences, such as norms, price changes, increases in leisure time, roles, and so forth. I believe that this point gives us reason to doubt the elaborate edifice of social science based on notions of "preference" or "metapreference" (though much of the edifice can remain if reconstructed on different foundations).

The next task is to separate positive, descriptive, and normative inquiries more sharply, and in the process to try to untangle relevant mental states and their influences. Of course it may the case that once we understand a person, or a group, very well, we will understand those mental states and their relation to external forces, and we may be able to make a wide range of predictions about how different forces will affect behavior.

\section{A nomalies}

A. Willingness T o Pay vs. Willingness T o Accept: The Place of Shame

Recent empirical work suggests that many claims in economics ${ }^{46}$ rest on an intriguingly false assumption, one that suggests that it may sometimes be impossible for government to take preferences "as they are." 47 The basic finding is this: The initial grant of an entitlement of some good $X$ to some person $A$ can make $A$ value $X$ far more than he would if $X$ had been initially allocated to B. (It also makes B value it less than he otherwise would.) The initial allocation-the legal rule saying who owns what, before people begin to contract with one another- serves to create, to legitimate, and to reinforce social understandings about presumptive rights of

46 Including the C oase T heorem.

47 See Thaler, Q uasi-Rational E conomics (1993); see also D ubourg et al., Imprecise Preferences and the W TP-W TA Disparity, 9 Journal of

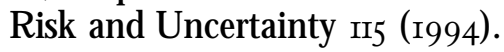


ownership. The effect of the initial allocation of a commodity or an entitlement is commonly described as the "endowment effect." "48

This point has received considerable empirical confirmation, often in the context of environmental amenities. 0 ne study found that people would demand about five times as much to allow destruction of trees in a park as they would pay to prevent the destruction of those same trees. ${ }^{49} \mathrm{~W}$ hen hunters were questioned about the potential destruction of a duck habitat, they said that they would be willing to pay an average of $\$ 247$ to prevent the loss-but would demand no less than \$1044 to accept it.50 In another study, participants required payments to accept degradation of visibility ranging from 5 to more than 16 times higher than their valuations based on how much they were willing to pay to prevent the same degradation $^{51}$ A related experiment tried to ascertain the "existence value" of a houseplant that grows like a pine tree. The subjects were told that any trees not sold or kept would be killed at the end of the experiment. The mean willingness to pay (WTP) to avoid the "kill" option was \$7.8r. The mean willingness to accept (W TA) payment to allow a tree to be killed was $\$ 18.43 .52$

48 It was first so-called in Richard Thaler, T oward a Positive Theory of C onsumer $C$ hoice, I J. E con. B ehavior and O rg. 39 (I980). This essay, along with others of similar interest, can be found in Richard Thaler, Q uasi-Rational E conomics (I990).

$49 \mathrm{D}$ an Brookshire and D on Coursey, $M$ easuring the $V$ alue of $a$ Public Good: An Empirical Comparison of Elicitation Procedures, 77 Am. E C. Rev. 554 (1987).

50 Judd $\mathrm{H}$ ammock and G. M. Brown, W aterfowl and W etlands: Toward Bioeconomic Analysis (1974); Robert Rowe et al.,, An Experiment on the Economic Value of Visibility, $7 \mathrm{~J}$. Env. Ec. and $M$ anagement I (I980).

51 Richard Thaler, T oward a Positive Theory of C onsumer Choice, I J. Econ. Behavior and Org. 39 (1980). A good overview is Elizabeth $H$ offman and $M$ atthew $L$. Spitzer, The Divergence Between $W$ illingness-to- $P$ ay and $W$ illingness-to- $A$ ccept $M$ easures of Value, W ash. U. L. Q. (I993).

52 See Rebecca Boyce et al., An Experimental Examination of Intrinsic V alues as a Source of the W T A - W T P Disparity, 82 A m. E con. Rev. I366 (1992). 
In general, the range of the disparity appears to vary from slight disparities to a ratio of more than four to one, with WTA usually doubling W TP. In field studies, environmental goods tend to reflect a disparity of factors from two to over ten. ${ }^{53}$ In some environmental experiments involving trees, the W TA/W TP ratio is extraordinarily high, ranging between $60 / \mathrm{I}$ and $90 / \mathrm{I}^{54}$

W hat explains this phenomenon? There are many possibilities, and none is likely to be exhaustive. $55 \mathrm{M}$ y suggestion is that some of the difference between W TP and W TA has a great deal to do with social norms and social meaning. If someone says that she is willing to accept $\$ X$ to allow the expiration of a species, the meaning of her action is altogether different from what it is if she says that she is willing to pay $\$ X$ (and no more) to prevent the extinction. Under prevailing social norms, one ought not to accept even a great deal of money to allow destruction of an environmental amenity- partly because the good at issue is collectively owned, partly because its loss may be irreversible, and partly because it is not thought to be commensurable with its cash equivalent (in the sense that it is not valued in the same way or along a single metric).

In these circumstances, people who announce their willingness to accept cash for the loss of a pond or a species feel shame. They believe that they are assuming responsibility for the destruction of something intrinsically valuable, not replaceable, and owned by many people. Because of the risk of shame, people will demand a great deal, and they may even refuse any amount is offered.56 By contrast, those who refuse to pay an enormous or infinite amount to save an environmental amenity do not feel the same degree of shame (if they feel shame at all). They are confronted with a different set of social norms.

53 See Boyce et al., supra note, at 1366 .

$54 \mathrm{D}$ avid $\mathrm{S}$. B rookshire and D on L. C oursey, M easuring the $V$ alue of a Public Good: An Empirical Comparison of Elicitation Procedures, 77 Am. E con. Rev. 554 (1987).

55 See Sunstein, Endogenous Preferences, Environmental Law, 22 J Legal Stud 217 (1993).

56 T hus in surveys nearly $50 \%$ of people sometimes refuse to name any amount. 
Take an analogy. If someone is asked how much she would be willing to accept to allow her dog's life to be shortened by six months- or how much she would be willing to accept to allow her dog to suffer severe pain for, say, one week- she might well say: "No amount is sufficient." The question is very different if a veterinarian is asking someone whether unusual and expensive medical procedures should be used to prolong a dog's life or reduce its pain. H ere the answer need not be: "No amount is too high."

Some intriguing work suggests that the disparity between W TA and WTP is connected with the assignment of moral responsibility for the destruction of environmental assets, which are perceived as intrinsic goods. The W T A measure assigns responsibility to the individual. The WTP measure does so more ambiguously. These findings are consistent with the norm-based explanation I am offering here. People want to avoid or to minimize the feeling that they have been morally culpable for producing the loss of an environmental amenity. ${ }^{57}$ Feelings of moral culpability are tightly connected with prevailing social norms.

\section{B. Shame, Altruism, and F re Riding}

The point relates to the first tale in Part I; we are now in a position to explain the apparent anomaly. W hen two people are to divide an amount given to them under the stated conditions, the offeror in the ultimatum game feels shame under prevailing norms- that he is demonstrating that he is a greedy and even horrible person - if he offers a penny or a dollar from a sum of (say) $\$ 200$. If a sum is given to two people under the conditions of the game, good people share; they do not try to keep almost all of the money for themselves. For his part, the offeree feels mistreated-treated in a contemptuous way-if a small or token amount is suggested. The social meaning of the statement, "H ow about five cents for you?" is contempt; the social meaning of responding, "G reat!" is a willingness to be dishonored.

Experimental work shows that people contribute to a shared good, and refuse to free ride, far more often than economists pre-

57 See Rebecca Boyce et al., An Experimental Examination of Intrinsic V alues as a Source of the W T A - W TP Disparity, 82 A m. E con. Rev. I366 (1992). 
dict. ${ }^{58}$ It also shows that agents are willing to cooperate, and hence to solve collective action problems without coercion, if most people are seen as cooperators; in such circumstances the social meaning of noncooperation is greed or selfishness. W hen a number of people free ride, and are seen to free ride, cooperation breaks down; in such circumstances the social meaning of cooperation is a willingness to be a "dupe" or a "sucker." The desire to contribute to a collective good is palpably a function of social norms. If social norms do not lead most people to contribute, contributions decrease steadily and dramatically. The second tale above should therefore be taken as a metaphor for many social outcomes. 59

$M$ y suggestion, then, is that apparent puzzles of rationality are often a product of social norms and moral judgments that are intertwined with those norms. Of course a full explanation would have to include an account of norms as well, and there is a risk that a reference to social norms will become a conclusory response to any anomalous results. But once we specify prevailing norms, we may be able to make robust predictions, and also to ask whether the anomalous behavior continues when it is not observed publicly.

These points suggest that it may well be impossible to distinguish between what is entitled by "rationality" and what is entailed by social norms. For the individual agent, rationality is a function of social norms. A norm-free conception of rationality would have to depend on a conception of what people's rational "interests" are in a social vacuum. Such a conception would not be very intelligible. It might seem natural to suppose that it is in people's interest not to pick up their garbage (see tale 2 ) and that social norms against littering add a kind of new or artificial factor to the individual calculus. But if we make this supposition, we are saying something about the individual's calculus without the antilittering norm; and what is the basis for any particular conception of how calculus will come out?

58 See 0 rbell et al., Explaining D iscussion-Induced C ooperation, $54 \mathrm{~J}$ of Personality and Social Psychology 8II (I988), $\mathrm{H}$ andbook of Experimental E conomics 26- 28, I4I-69, 409- II (J. Kagel and A. Roth eds. I995). N ote also that cooperation increases when people can talk with one another; discussion significantly raises contribution rates, perhaps because it increases empathy and the shame associated with noncooperation.

59 See T. Kuran, Private T ruths, Public Lies 48- 49 (1995). 
No such conception will be free of an array of ends, seen as such partly because of social influences, including social norms. W hy, for example, is picking up garbage a cost rather than a benefit? A $\mathrm{n}$ implicit (but undefended and obscure) state of nature theory seems to lie at the heart of many distinctions between social norms and rationality, or rational self-interest. To become separated from social norms, a conception of rationality must be frankly normative and defended as such.

VII. G overnment A ction: $0 \mathrm{n}$ A utonomy and T ools

Sometimes it seems desirable to change choices. Government might attempt to change choices by changing social norms, social meaning, and social roles. In fact changes in norms may be the cheapest and most effective way to make things better, whatever are our criteria for assessing that matter. The relation between behavior and norms has yet to receive sustained attention; when we attend to that relation, we see that government has a policy instrument of great potential value.

To be sure, private power to create norm communities may make government action less necessary or less desirable. 0 ften the best step is to allow those communities to be formed and to see how they work out. But sometimes it is too costly for individuals to create or join those communities, and sometimes the generally held norm is too damaging to human well-being. These issues cannot be solved in the abstract; the judgment depends on the details. But it is clear that norms can create problems of various sorts and that collective action may be required.

A. N orms and Paternalism

Common objections to "paternalism" or "perfectionism" are not easy to sustain in such contexts. Recall that people usually do not choose norms, meaning, and roles; all of these are (within limits) imposed. As I have said, it would be ludicrous to deplore norms, meaning, and role; they make life possible and they much facilitate social engagement. They provide the context within which free interaction is possible. Nonetheless, some of them operate as severe limits on autonomy or well-being, and certainly they should not be 
treated as fixed or as given regardless of their content or consequences.

Private groups can test or even change norms. Indeed, the testing of current norms, meaning, and roles is a crucial function of groups intermediate between citizens and the state. Religious groups are in this sense norm entrepreneurs; the same is true for environmental and civil rights organizations. But sometimes private groups are unable to produce desirable change on their own. This is a point missed by the idea that the sole basis for government action is to avoid force, fraud, and "harm to others." O bstacles to autonomy and to good lives can also come from bad roles, norms, and meaning.

O ften all or most people would on reflection like to see a change in a particular norm, 60 and they cannot bring the change about on their own, because in his individual capacity, each person has limited power to alter meaning, norms, or role. The case of mandatory helmets for hockey players is a familiar example. ${ }^{61} \mathrm{H}$ ockey players may prefer not to wear helmets if the meaning of helmet-wearing is cowardice; but their preferred solution, available only through a mandate, is a system in which all are required to wear helmets, and hence players wear helmets without signaling cowardice. Of course shifts in norms, meaning, and roles are pervasive. Consider, for example, changing norms with respect to smoking, littering, drug use, polluting, racial discrimination, sexual relations outside of marriage, the role of women and men, and interracial relationships.

In fact it is often hard to know what people would "like" or prefer, because their judgments and desires are entangled with norms, meaning, and role, and because once one or more of these is changed, they may be better off either objectively or subjectively. If government changes the social meaning of smoking (see the third tale above), has it acted illegitimately? W hat if most people, or most smokers, would, on reflection, want smoking to have a different meaning? O $r$ suppose that government tries to change an aspect of a certain social role, like that of unwed fathers, high school teachers, homosexuals, or workers. Surely the consequences of the change matter; surely it matters if the change is supported by (most or all)

60 Their desire to this effect is likely to be a product of norms that are being held constant. See TAN supra.

61 See Schelling, supra note; L essig, supra note. 
unwed fathers, high school teachers, homosexuals, or workers, and if members of each group face a collective action problem.

\section{B. Tools}

Suppose that government is concerned to change norms, meaning, or roles. It has many different tools for doing so; some of these are mildly intrusive while others may foreclose choice. Government may restrict itself to education, understood as simple statements of fact. W e have seen that norms, meaning, and role can be a function of beliefs, and beliefs are mutable. Perhaps prevailing beliefs are false and warrant correction. People may think that AIDS is a disease limited to homosexuals, that smoking does not hurt nonsmokers, or that there is no relation between cholesterol and heart disease or between diet and cancer. C hanging norms with respect to smoking are almost certainly a result-at least in part- of information from government about health risk. In principle, there should be no objection to governmental efforts to correct false beliefs, even if the correction affects norms, meaning, and role. In fact the change along this dimension may be the most important consequence of education, which may, for example, remove certain kinds of shame.

Government may also attempt to engage in persuasion, understood as a self-conscious effort to alter attitudes and choices rather than simply to offer information. Consider the third tale above; assume that some such advertisement had been issued by state officials. Perhaps it would have been effective (though its social meaning would have been altogether different if issued by officials rather than by members of the private African-A merican community). The "Just Say $\mathrm{N} \mathrm{o"} \mathrm{policy} \mathrm{for} \mathrm{drugs} \mathrm{falls} \mathrm{in} \mathrm{the} \mathrm{category} \mathrm{of} \mathrm{attempted} \mathrm{per-}$ suasion; so too with efforts to control AID S by strongly encouraging abstinence from sex or the use of condoms. H ere government does not restrict itself to provision of information, but instead uses rhetoric and vivid images to change norms, meaning, or role, and in this way to persuade people to choose a certain course.

Some people think that although the provision of information can be justified, government may rarely or never attempt to persuade. ${ }^{62}$ But if norms, roles, and meanings are beyond individual

62 See V iscusi, supra note. 
control, and sometimes bad, this thought is hard to sustain, at least if government is subject to democratic controls.

Consider in this connection the problem of smoking and the lessons of the second tale above. A mong blacks between i8 and 24, the rate has fallen for $37.1 \%$ in 1965 , to $31.8 \%$ in 1979 , to $20.4 \%$ in I987, to 1 I. $8 \%$ in $1991 .{ }^{63} \mathrm{~A}$ mong whites in the same age group, the rate fell from $38.4 \%$ in 1965 to $27.8 \%$ in 1987 -but it has remained more or less constant since that time.64 The change within black teenagers is universally described as a "public health success story," but one that government officials cannot explain. Though no one has a full account of this phenomenon, changing social norms appear to be playing a substantial role. Smoking does not have the same cachet in the A frican-A merican community that it has among whites. If government could bring about a general change in social norms- through, for example, attempts at persuasion-it is hardly clear that there would be a good objection to its behavior.

Government might also use economic instruments to tax or subsidize choices. Of course education is assisted publicly, as are day care, museums, and public broadcasting (at least as of this writing). A lcoholic drinks, tobacco products, generation of waste, and some polluting activities are met with taxes (though some of these are subsidized too). W e can understand some economic incentives as efforts in part to counteract social meaning, social norms, or social roles with financial benefits or penalties designed to produce a good "equilibrium." A social meaning that is perceived to be bad might be "matched" with a financial incentive.

Government might also impose time, place, and manner restrictions. It might ban smoking in public places. It might say that television shows containing violence may be shown only in certain time slots. It might require government itself to choose low-polluting motor vehicles. It might ban affirmative action in the public sector but allow it in the private sector. Strategies of this kind might affect the social meaning of the relevant activity very generally. But they do not foreclose entirely choice; they channel it instead.

The most intrusive kind of government action is of course straightforward coercion. Thus government might prohibit the use of

63 Statistical A bstract of the U nited States at I43.

$64 \mathrm{Id}$. 
certain drugs; require everyone to recycle or buckle their seatbelts; or make education mandatory for people under a certain age.

\section{G overnment A ction: Four $G$ rounds}

In this section I discuss several grounds for governmental efforts to change norms, meaning, and role. The unifying theme is the expressive function of law - the function of law in expressing social values and in encouraging norms to move in particular directions. I do not discuss any of these grounds in detail; I offer instead a brief and far from definitive sketch of some possibilities.

\section{A. Some U nusual Collective Action Problems}

r. Standard Formulations and Conventional Accounts. In a standard formulation, many social practices would be inefficient if not for certain social norms; the norms solve a collective action problem. They do the work of law. They may provide conventions on which everyone voluntarily settles; table manners are examples. 0 r they may solve prisoner's dilemmas through social sanctions imposed on deviants; this is true of the idea that people should clean up after their dogs. And because of the absence of good norms, some existing practices are highly inefficient. T ake the standard case of littering, captured in the second tale in Part I. Under conventional assumptions, each person may well litter- if the costs of throwing things in the garbage are wholly internalized, whereas the benefits of doing so are spread across a wide range of people. In the conventional account, "rational" individuals, acting in their "self-interest," will produce a great deal of litter, and perhaps so much that legal regulation is ultimately required. This idea helps explain legal responses to environmental degradation, as in the cases of mandatory recycling, taxes on or fees for polluting activity, and command and control regulation.

2. Puzzles. But many questions might be raised about the standard formulation and the conventional account. The relevant changes do not bring about Pareto improvements. Some people are losers; in fact many people may be losers, for example those who dislike helmets and seatbelts no matter the number of people who wear them. W e should distinguish the simplest cases-in which all or nearly all people favor a change in norms-from cases in which 
there are bare majorities. If everyone would favor a situation in which people pick up after their dogs and this result cannot be brought about without government action, the case is easy: G overnment action should be initiated. But if $65 \%$ of people would favor the change, and $35 \%$ like the status quo, we have a harder case. To decide whether government action is appropriate, it is necessary to take a stand on a large question in political theory; the fact that norm-change is involved means that the setting is unusual, but not the basic analysis.

E ven more fundamentally, the words "rational" and "self-interest" obscure a great deal, since they take so much for granted. There is no sharp dichotomy between rationality and social norms or between self-interest and social norms; what is rational and what is in an agent's self-interest are functions of social norms. ${ }^{65}$ Return to our second story above and suppose that there is a social norm to the effect that everyone should pick up litter. If the norm is in place, people who act in their rational self-interest will not litter. In the second tale, were the nonlitterers or the control group acting in its rational self-interest? W hat is rational, and what promotes self-interest, depends on many exogenous factors, including existing norms.

There is a further point. Suppose that there is no norm against littering; that people think that there is too much litter; and that they would like to create a new, anti-littering norm. W ould it be right to say that this is a case in which a collective action problem would be best served with the aid of social norms? The statement would not be false but it would be misleading and incomplete. What makes the collective action problem is an array of individual judgments and desires that are themselves (in all likelihood) a function of social norms. If people "want" a new norm, their desire probably stems from many other norms- such as norms favoring clean rather than dirty parks, norms in favor of shared rather than maldistributed burdens, norms in favor of solutions through norms rather than coercion or fines.

65 A norm-free conception of interest would have to depend on a conception of what people's "interests" are in a social vacuum. Such a conception would not be very intelligible. 
W hen a situation is supposed to create a prisoner's dilemma that would be satisfied by some norm Z, the situation presupposes a range of norms $A$ through $Y$ that are being held constant and not being put in contention. Then the question becomes: $W$ hy is it that norm $Z$ (say, the norm with respect to littering) is put into question, rather than some other norm (say, the norm favoring clean parks)? This question has yet to be addressed in existing work on collective action and social norms. An answer might be found in one of two ways. W e might put at issue those norms that are not part of the relevant agents' own deepest convictions and self-understandings. Typically the norms sought to solve collective action problems seem to be a form of "tinkering," encouraging conduct that preserves what people believe most deeply, have thought through, or most take for granted. A lternatively, we might not look to agents' convictions but venture instead an objective account of human needs and human interests. O n such an approach, a collective action problem exists because if agents could agree on the norm in question, things would be better rather than worse. It is not clear, however, that this way of seeing things can coexist with ordinary understandings of collective action problems, which are rooted in subjective desires. A possible conclusion of what I have said thus far is that in the context of norms, the ordinary understandings face a conceptual problem.

3. Legal R esponses. H owever rationality and self-interest are defined, a well-functioning society needs many norms that make it rational for people, acting in their self-interest, to solve collective action problems. When such problems exist, it is because of the social norms that make rational self-interest take a certain form. A large task is therefore to try to inculcate the relevant norms. E ffective responses promote efficiency and simultaneously enhance a form of freedom, by producing outcomes that citizens reflectively judge best but cannot obtain on their own.

$M$ uch legal regulation has this goal. Such regulation might even consist of direct coercion, designed to generate good norms and to pick up the slack in their absence. There are laws designed to ensure that people pick up after their dog; that people do not litter; that people do not smoke in certain places. These laws are rarely if ever enforced through criminal prosecutions. But they have an effect in shaping social norms and social meaning. They help to inculcate both shame and pride; they help define the appropriate sources of 
these things. They readjust the personal calculation, making what is rational, and what is in one's self-interest, different from what they were before.

The key point is that such a change may be supported by the reflective judgments of all or most people. $W$ hen it is, there should be no objection in principle. ${ }^{66}$ The point very much bears on the phenomenon of norm bandwagons. People may actually reject existing norms but fail to state their opposition publicly, and once public opposition becomes less costly, new norms may rapidly come into place.

\section{B. Autonomy}

Of course a liberal society might want to ensure that all of its citizens are autonomous. For the moment let us understand the notion in a way that leaves open many questions but that will be helpful for our limited purposes here. A citizen can be understood as autonomous insofar as she is able to choose among a set of reasonably good options and to be reflective and deliberative about her choice. 67 A society can be understood as self-governing, and as politically autonomous, to the extent that its citizens face a range of reasonably good options and exercise capacities of reflection and deliberation about their choice.

It should be clear that social norms, meanings, and roles may undermine individual autonomy. A bove all this is because norms can compromise autonomy itself, by stigmatizing it. People may believe, on reflection, that the act of being well-educated should not be a source of shame; but in some communities, a good deal of education may be inconsistent with prevailing social norms. O $\mathrm{r}$ exposure to diverse options, and reflection about which is best, may seem inconsistent with existing norms. In such cases autonomy cannot exist without collective assistance; people are able to produce the norms, meanings, and roles that they reflectively endorse only with governmental involvement. Something must be done collectively if the situation is to be changed.

66 Some cases can be imagined in which the response would be invasive of rights and therefore by hypothesis unacceptable.

${ }^{67} \mathrm{C} \mathrm{f}$. E. A nderson, V alue in E thics and E conomics ( 1993 ). 
To promote autonomy, a society might seek to ensure that everyone has a minimal degree of education, a certain level of exposure to diverse conceptions of the good, and what might be considered the material bases of autonomy: food, shelter, and freedom from criminal violence. In modest forms this project is fully compatible with political liberalism; perfectionalist liberals might insist on a good deal in this vein in order to allow people to be (more or less) masters of the narratives of their own lives. In either case, social norms can undermine the liberal project, and government might try to alter them in order to promote autonomy. Prevailing norms and meanings may be adaptive to limits in existing opportunities ${ }^{68}$; but they are nonetheless an obstacle to autonomy.

A government that seeks to promote autonomy might well work against efforts by subcommunities to require conformity to a single defining creed. In fact conflicts between antidiscrimination principles and religious liberty have everything to do with perceived limits on governmental ability to change norms, meanings, and roles in subgroups that deny autonomy. These conflicts are generally resolved in favor of subgroups, especially in the area of sex equality. But if we attend to the autonomy-denying effects of norms and meaning, it might well make sense to resolve the conflicts against subgroups, even religious ones.

\section{Caste}

$\mathrm{M}$ any problems of discrimination actually raise issues of caste. W e might say that we have a system with caste-like features when a highly visible and morally irrelevant factor is turned, by social and legal practices, into a systematic source of social disadvantage. ${ }^{69} \mathrm{~A} n$ important and disastrous feature of this situation is the signaling effect of the characteristic that is shared by lower caste members. That characteristic promotes a certain social role for caste members, since it is associated with a range of undesirable or otherwise stigmatizing

${ }^{68} \mathrm{C}$ f. Jon E Ister, Sour G rapes (1983); A martya Sen, Commodities and Capabilities (1985). Just as preferences can be adaptive to an unjust status quo, so can norms and meanings be a predictable outgrowth of limited autonomy or heteronomy.

69 See Cass R. Sunstein, The Partial Constitution ch. Io (1993); Sunstein, The Anticaste Principle, 92 M ich L Rev 24IO (1994). 
traits. 0 ften an attack on a caste system amounts to an attack on that social role and its associated social norms- especially as a result of behavioral norms shared, or thought to be shared, by members of the lower caste. ${ }^{70} \mathrm{~F}$ or lower caste members, the problem is that the shared characteristic carries with it a meaning-stupidity, passivity, venality - that cannot be controlled by individual agents.

Suppose, for example, that it was thought important to alter social norms about gender relations. The social role of "being a woman" is associated with a wide range of social norms and social meanings. There are many examples from the present and recent past. Thus it may be that women do the majority of domestic labor. In these circumstances, a man who does most of the domestic labor might seem odd, or in some way woman-ish, and a woman who asks for something like equality in domestic labor might seem odd, selfish, or in some way man-ish. Or a woman in her fifties might be seen in a way fundamentally different from a man in his fifties, be cause of social norms associated with gender. Or a single woman might be stigmatized, or inquired about, in ways fundamentally different from what happens to a similarly situated man. Or a woman who complains about apparently mild forms of sexual harassment might seem to be a radical, a troublemaker, or someone without a sense of humor.

A wide range of "choices" might emerge from the underlying social norms. These choices might reflect adaptation by lower caste members to existing injustice; they might be a product of the social opprobrium attached to violation of social norms by lower caste members. ${ }^{71}$ The choices might even be called "preferences"; certainly desires can be affected. But many women believe on reflection that the social meaning of being a woman is bad for them and that it should be changed. These women face a collective action problem that may be best solved with government action. In any case a caste system tends to deny autonomy to lower caste members.

$70 \mathrm{~N}$ ote in this regard Richard W right's suggestion that unlike most blacks in the south, he would "act straight and human." W right says that most blacks, even those who felt great resentment, pretended to accept their inferior position. See W right, Black B oy 253 (I945).

71 See the discussion of adaptation of preferences of lower caste members in India in T imur Kuran, Private Truths, Public L ies I96- 204 (1995). 
This is simply a stylized discussion of the problems faced by people who live within a caste system, ${ }^{72}$ and who might seek to enlist the law to make things better. Such people face a free rider problem that pervasively undermines reform efforts.

\section{E. Expressive Action}

$M$ any laws have an expressive function. They "make a statement" about how much, and how, a good or bad should be valued. They are an effort to constitute and to affect social meanings, social norms, and social roles.

Of course human goods are valued in different ways; people have a wide variety of evaluative stances toward relationships and goods. $L$ aws with expressive functions are often designed to promote a certain way of valuing certain goods. $M$ any such laws are intended to say that specified goods should be valued in a way that deters thinking of them as mere objects for use. L aws forbidding the purchase and sale of certain goods can be so understood. A ban on the sale of children is designed (among other things) to say that children should be valued in a way that forbids the acceptance of cash as a reason for taking them out of parental care. A ban on vote-selling can be viewed similarly. W e might understand such a law as an effort to make a certain statement about the pricelessness- not the infinite value - of the right to vote. In the environmental area, de bates over market valuation are partly debates over this question. ${ }^{73}$

L aws with expressive justifications may or may not be designed to have social consequences. Some such laws might be defended on the ground that they will affect social norms and move them in appropriate directions. At this stage there are empirical questions: D o laws affect social norms and social meanings? Under what conditions? But laws with expressive justifications might be defended for the statement they make, quite independently of consequences. Certainly this is true for individual behavior. People may avoid a

72 See Kuran, supra note, at I34 ("Because society will generally ostracize anyone who abandons the caste system, the potential member of an anticaste colony is likely to withhold his participation until it appears likely to succeed. W ith other potential members reasoning likewise, the colony will remain unformed.").

73 See S. K elman, W hat Price Incentives? (1983). 
certain course of action because of the meaning of that course, apart from consequences.

\section{B LOCKED G ROUNDS}

W hat I have suggested here should unsettle some common understandings about government "paternalism" and "meddling." If private choices are a function of roles, norms, and meanings over which private people have no sovereignty, many imaginable initiatives are consistent with individual autonomy, rightly conceived. But this conclusion ought not to suggest that government should be licensed to do however it wishes.

O ften government action should be rejected on simple pragmatic grounds- because, for example, it is likely to be futile or counterproductive. The "just say no" campaign with respect to drug use probably falls in this category. Or perhaps government has mistakenly concluded that there is a collective action problem calling for governmental response. Perhaps most people are happy that littering is not stigmatized; perhaps efforts to stigmatize teenage smoking will backfire and make smoking seem bold or glamorous. If government action would be ineffective or counterproductive, it should not go forward.

It is also true that government interference with norms, role, or meaning might be confused or otherwise wrong. Government might compound a collective action problem, respond to well-organized private groups promoting unjust goals, or aggravate a caste-like situation. Imagine an effort to promote the use of cigarettes, alcohol, or drugs, or to discourage the buckling of seatbelts, or to increase the opprobrium associated with the role of being a homosexual. $\mathrm{N}$ othing I have said suggests that government is not properly criticized when it engages in activity of this sort. But any such criticism should be on the merits, not on the ground that government may not interfere with private preferences or choices.

There is a final point. A liberal society limits the permissible bases for governmental action. It might well describe the limits as "rights." A full account of these limits would be far too ambitious for an essay of this sort; but a few notes will be helpful.

Some government action designed to change norms, meaning, and role might be based on religious grounds; these should be 
banned as reasons for public action. A t least in the A merican constitutional system, for example, it is unacceptable for government to attempt to legislate on the ground that the divinity of Jesus Christ requires a certain state of affairs. So too, it would be unacceptable to base government action on grounds that deny the basic equality of human beings- as in efforts to encourage norms that treat members of racial minorities as second-class citizens.

In any case some human interests are properly denominated rights, and efforts to change norms, meanings, and role should not be allowed to invade rights. ${ }^{74} \mathrm{M}$ any imaginable efforts ought to be rejected because of this risk. Consider, for example, a suggestion that the meaning of refusing government officials into your home is now "personal courage and independence"- accompanied by the not implausible thought that things would be better if the meaning were "unpatriotic unwillingness to cooperate with the crime-fighting effort," culminating in a proposal that everyone should be required to open their homes to the government. There is a collective action here. But if it is believed that people should have a right to keep government officials from their homes, this proposal should be rejected.

Political liberals go further and urge rejection of any ground for action that is based on a "comprehensive view."75 Of course there are many complexities in this claim. W hat is important for present purposes is that on any sound view of liberalism, there is no general basis, in principle, for objection to proposals of the sort I have suggested. Political liberals ought to acknowledge, for example, that social roles and social meanings may undermine the equality and liberty of citizens and that changes require collective action. The constraints imposed by political liberalism impose no bans on those changes. rights.

74 I do not mean to say anything here about the status or basis of

75 See John Rawls, Political Liberalism (1993); Charles Larmore, Patterns of M oral Complexity (1988). 
Conclusion

$\mathrm{M}$ any claims about the appropriate limits of law are insufficiently attentive to the pervasive effects of social norms, social meanings, and social roles. In fact these effects have yet to receive much attention. ${ }^{76}$ B ut the behavioral effects of law are an important matter for lawmakers to understand, and those effects have everything to do with social norms. An understanding of norms will therefore bear a great deal on effective regulatory policy. $M$ any of the most dramatic gains in health and safety policy are a product of changes in norms, meanings, and role.

$\mathrm{N}$ orms relate to some broader issues as well. $\mathrm{O} f t e n$ it is said that the common law, and a liberal regime dedicated to freedom, take "preferences" as they are and do not seek to change them. But the term "preferences" is highly ambiguous. If the term is meant to refer to "choices," it should be understood that choices are very much a function of context, including governing norms, meanings, and roles. C ertainly the particular choices made by people in markets-in their capacity as consumers or laborers- do not suggest global or acontextual valuations of relevant goods. If the term "preferences" is meant to refer not to choices but to the mental states behind choices, it is important to recognize that those mental states include assessments of social norms, the expressive meaning of acts, and the expectations associated with a dazzling variety of social roles. N orms and roles affect both public action and public talk, in ways that can much disguise how people think privately. This point has large implications. In many settings, it would be best to dispense with the idea of "preferences." M oreover, norms can be far more fragile than they appear; hence "norm entrepreneurs" can help solve collective action problems, and hence "norm bandwagons" are common.

W hile social life would be impossible without norms, meanings, and roles, individual people have little control over these things. The result can be severe limits on human well-being. Certainly there is a problem with existing norms when all or almost all people would seek a change and when existing norms deny people the preconditions for autonomy. In fact lives are shortened and unjustified in-

76 The principal contributions are L essig, note supra, and from a different direction, Ellickson, note supra. 
equalities are perpetuated by the existence of many current norms. People need collective help if they want to change norms, meaning, or roles. Collective help may be futile or counterproductive; it may be illegitimately motivated. But these matters require an inquiry into context. The issue should not be foreclosed by resort to confusing claims about the need to respect private choice.

This W orking paper is a version of a chapter of a book, Cass R. Sunstein, Free M arkets and Social Justice, forthcoming, 1997. R eaders with comments should address them to:

Cass R. Sunstein

K arl N . L lewellyn D istinguished Service Professor

The Law School

The University of $C$ hicago

IIII E . 6oth Street

Chicago, Illinois 60637 


\section{C hicago W orking Papers in $L$ aw and E conomics (Second Series)}

I. W illiam M. Landes, Copyright Protection of L etters, Diaries and $\mathrm{O}$ ther Unpublished W orks: A $\mathrm{E}$ E conomic A pproach (July I99I).

2. Richard A. E pstein, The Path to The T. J. H ooper: The Theory and $\mathrm{H}$ istory of Custom in the L aw of T ort (A ugust 199I).

3. Cass R. Sunstein, On Property and Constitutionalism (September 1991).

4. Richard A. Posner, Blackmail, Privacy, and Freedom of Contract (F ebruary 1992).

5. Randal C. Picker, Security Interests, M isbehavior, and Common Pools (F ebruary i992).

6. Tomas J. Philipson \& Richard A. Posner, O ptimal Regulation of aids (A pril 1992).

7. Douglas G. Baird, Revisiting Auctions in Chapter 11 (A pril I992).

8. W illiam M . L andes, Sequential versus U nitary Trials: An E conomic A nalysis (July 1992).

9. William M. Landes \& Richard A. Posner, The Influence of E conomics on Law: A Q uantitative Study (A ugust 1992).

Io. A lan 0 . Sykes, $T$ he $W$ elfare $E$ conomics of Immigration $L$ aw: A Theoretical Survey With An Analysis of U.S. Policy (September 1992).

II. Douglas G. Baird, 1992 Katz Lecture: Reconstructing Contracts (N ovember 1992).

I2. Gary S. Becker, The Economic W ay of Looking at Life (January I993).

I3. J. M ark Ramseyer, C redibly Committing to E fficiency W ages: Cotton Spinning Cartels in I mperial Japan (M arch 1993). 
I4. C ass R. Sunstein, Endogenous Preferences, Environmental L aw (A pril I993).

15. Richard $A$. Posner, W hat Do Judges and Justices $M$ aximize? (The Same Thing E veryone E Ise D oes) (A pril r993).

I6. L ucian A rye Bebchuk and Randal C. Picker, Bankruptcy Rules, $M$ anagerial Entrenchment, and Firm-Specific $H$ uman $C$ apital (A ugust 1993).

17. J. M ark Ramseyer, Explicit Reasons for Implicit Contracts: The L egal L ogic to the Japanese M ain Bank System (A ugust I993).

18. W illiam M . L andes and Richard A. Posner, The E conomics of A nticipatory A djudication (September 1993).

19. Kenneth W. D am, The E conomic Underpinnings of Patent L aw (September 1993).

20. Alan 0 . Sykes, An Introduction to Regression A nalysis (O ctober 1993).

2I. Richard A. Epstein, The Ubiquity of the Benefit Principle (M arch 1994).

22. Randal $\mathrm{C}$. Picker, A $\mathrm{n}$ Introduction to $\mathrm{G}$ ame Theory and the Law (June 1994).

23. W illiam M. Landes, Counterclaims: An Economic A nalysis (June 1994).

24. J. $M$ ark Ramseyer, $T$ he $M$ arket for $C$ hildren: $E$ vidence from E arly M odern Japan (A ugust 1994).

25. Robert H. Gertner and Geoffrey P. M iller, Settlement E scrows (A ugust 1994).

26. Kenneth W. Dam, Some Economic Considerations in the Intellectual Property Protection of Software (A ugust 1994).

27. C ass R. Sunstein, Rules and Rulelessness, (O ctober 1994).

28. D avid F riedman, M ore Justice for Less M oney: A Step B eyond Cimino (D ecember 1994).

29. Daniel Shaviro, Budget Deficits and the Intergenerational D istribution of L ifetime C onsumption (January 1995). 
30. Douglas G. Baird, The Law and Economics of Contract $D$ amages (F ebruary 1995)

31. Daniel Kessler, Thomas M eites, and Geoffrey P. M iller, Explaining Deviations from the Fifty Percent Rule: A M ultimodal A pproach to the Selection of Cases for Litigation (M arch 1995).

32. G eoffrey P. M iller, D as Kapital: Solvency Regulation of the A merican B usiness E nterprise (A pril 1995).

33. Richard C raswell, F reedom of C ontract (A ugust 1995).

34. J. M ark Ramseyer, Public C hoice (N ovember 1995).

35. Kenneth W. Dam, Intellectual Property in an A ge of Software and Biotechnology (N ovember 1995).

36. Cass R. Sunstein, Social Norms and Social Roles (January I996). 